\title{
PENGARUH DISIPLIN KERJA DAN KOMPETENSI TERHADAP KINERJA GURU PADA SMK NEGERI 2 TANGERANG
}

\author{
Dewi Lestari ${ }^{1)}$ \\ 1) dosen universitas pamulang, email : dewilestari7453@gmail.com
}

\section{ARTICLES}

INFORMATION

ABSTRACT

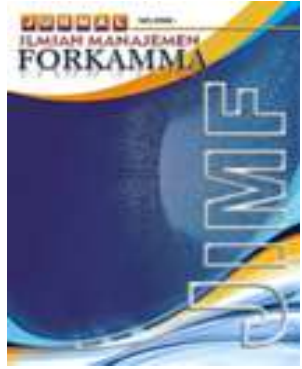

\section{JURNAL ILMIAH MANAJEMEN FORKAMMA}

Vol.2, No.3, Juli 2019 Halaman : $1-15$

(c) LPPM \& FORKAMMA

Prodi Magister Manajemen UNVERSITAS PAMULANG

ISSN (online) : 2599-171X

ISSN (print) : :2598-9545

\section{Keyword :}

Work Discipline, Competence, Teacher Performance.

JEL. classification : C33, G20, G23, N65

Contact Author :

PRODI
MAGISTER MANAJEMEN \&
FORKAMMA UNPAM
JL.Surya Kencana No.1 Pamulang
Tangerang Selatan - Banten
Telp. (021) 7412566, Fax (021) 7412491
Email :
jurnalforkamma.unpam@gmail.com

Tujuan dari penelitian ini adalah untuk mengetahui pengaruh disiplin kerja dan kompetensi terhadap kinerja guru pada SMK 2 Tangerang Selatan.

Metode yang digunakan adalah mixed method dengan analisis data berupa uji instrumen, uji asumsi klasik, analisis regresi, analisis korelasi, analisis determinasi dan uji hipotesis.

Hasil penelitian menyimpulkan bahwa baik secara parsial maupun secara simultan variabel disiplin kerja dan kompetensi berpengaruh signifikan terhadap kinerja guru pada SMK Negeri 2 Tangerang Selatan dengan persamaan regresi $Y$ $=9,041+0,358 \times 1+0,423 X 2$. Nilai koefisien korelasi sebesar 0,752 dan besarnya pengaruh sebesar $56,6 \%$. Uji hipotesis diperoleh nilai probability signifikansi $0,000<0,05$.

The purpose of this study was to determine the effect of work discipline and competence on teacher performance at South Tangerang 2 Vocational High Schools.

The method used is mixed method with data analysis in the form of instrument test, classic assumption test, regression analysis, correlation analysis, analysis of determination and hypothesis testing.

The results of the study concluded that both partially and simultaneously the variables of work discipline and competence had a significant effect on teacher performance at SMK Negeri 2 South Tangerang with the regression equation $Y=9.041+$ $0.358 \times 1+0.423 \times 2$. The value of the correlation coefficient is 0.752 and the amount of influence is $56.6 \%$. Hypothesis testing obtained a probability value of $0,000<0.05$. 


\section{A. Pendahuluan}

\section{Latar Belakang Masalah.}

Pendidikan sangat penting dalam menciptakan manusia yang andal dan terampil di masa depan. Oleh karena itu, pendidikan resmi dan informal diperlukan untuk mengembangkan sumber daya manusia untuk kepentingan pembangunan di semua bidang. Guru sebagai pendidik yang bertindak sebagai pencetak sumber daya manusia, dituntut untuk dapat memenuhi harapan dan keinginan masyarakat yang semakin meningkat. Jadi sekolah sebagai organisasi pendidikan harus berusaha untuk memeriksa berbagai kekuatan dan kelemahan dengan mencoba melakukan perbaikan terus-menerus dan mengidentifikasi berbagai tantangan untuk meningkatkan prestasi siswa. Jika pendidikan suatu negara ingin maju, maka perlu didukung oleh tenaga kependidikan yang memiliki kompetensi dan tuntutan yang sesuai dengan tanggung jawab seorang pendidik. Untuk itu perlu kerja sama sinergis antara semua orang yang terlibat di dalamnya, baik warga sekolah, pemerintah.

Berdasarkan ketentuan undang-undang Departemen Pendidikan Nasional (2003), tugas utama seorang guru adalah sebagai pendidik, manajer, inovator dan motivator bagi siswa. Guru adalah salah satu sumber daya manusia yang penting dan memiliki pengaruh besar pada kualitas pendidikan. Guru adalah orang yang memiliki pengaruh dominan dan paling penting dalam pendidikan formal secara umum. Seiring dengan peran guru sebagai pendidik, guru harus menguasai kompetensi mereka dan memiliki disiplin kerja sehingga mereka dapat meningkatkan kinerja guru baik di sekolah maupun di luar sekolah.

Guru adalah salah satu komponen yang menempati posisi sentral dan sangat strategis dalam sistem pendidikan. Guru adalah faktor dominan dalam kaitannya dengan peningkatan kualitas pendidikan, karena guru merupakan bagian yang tidak terpisahkan dari keseluruhan sistem pendidikan yang terlibat langsung dalam proses belajar mengajar, guru yang memainkan peran langsung dalam mengajar dan mendidik. Pentingnya komponen guru sangat menentukan terhadap pelaksanaan pendidikan berkualitas, hanya dengan guru yang kompeten, profesional dan memiliki kepribadian yang baik sehingga kegiatan belajar mengajar dapat berlangsung dengan lancar dan berkualitas.

Menurut Hasibuan (2013) "Disiplin adalah kesadaran akan sikap seseorang yang secara sukarela mematuhi semua peraturan dan sadar akan tugas dan tanggung jawabnya, sehingga ia akan mematuhi atau melakukan pekerjaannya dengan baik, bukan karena paksaan". Sedangkan menurut Djatmiko (2006) "Guru dituntut memiliki kinerja yang mampu memberikan dan mewujudkan harapan dan keinginan semua pihak, terutama masyarakat umum yang telah mempercayai sekolah dan guru dalam membina siswa. Kinerja guru selalu menjadi keprihatinan karena merupakan faktor penentu dalam meningkatkan prestasi belajar dan memiliki peran dalam meningkatkan kualitas lulusan sehingga kinerja dan total dedikasi serta loyalitas layanan akan menjadi pusat perhatian di sekolah".

Salah satu yang mendukung keberhasilan sekolah adalah kinerja guru. Banyaknya sekolah tidak mencerminkan kualitas pendidikan yang tinggi di Indonesia. Kita dapat melihat bahwa banyak sekolah memiliki guru yang belum memaksimalkan kompetensinya melalui pengembangan profesional dan cenderung muncul ketika mereka berada di depan kelas.

Kinerja guru menurut Supradi (2014) "Kinerja guru adalah kemampuan seorang guru untuk melakukan tugas belajar di sekolah dan bertanggung jawab untuk siswa di bawah bimbingannya dengan meningkatkan prestasi belajar siswa". Selain itu, kesadaran guru tentang peningkatan kompetensi profesional dan berperilaku sesuai dengan tuntutan profesi akan sangat mempengaruhi peserta didik siswa. Komitmen guru diperlukan untuk kelangsungan sekolah sebagai organisasi pendidikan. 
SMK Negeri 2 Tangerang adalah salah satu sekolah menengah kejuruan negeri di Tangerang memiliki 4 keterampilan kompetensi yaitu Multimedia, Akuntansi, Teknik Sepeda Motor, dan Teknik Kendaraan Ringan. Berdiri pada tahun 2008, dengan nama awalnya adalah SMK Negeri 8 Pondok Aren. Kemudian dengan perluasan wilayah, bagian dari Kabupaten Tangerang menjadi Tangerang Selatan, Sekolah Menengah Kejuruan Pondok Aren 8 yang memasuki wilayah Tangerang Selatan, diubah menjadi SMK Negeri 2 Tangerang Selatan. Memiliki 4 kompetensi keahlian, yaitu: Multimedia, Akuntansi, Teknik Sepeda Motor, dan Teknik Kendaraan Ringan. Keberhasilan mencapai tujuan hanya akan diperoleh jika guru bekerja dengan kinerja maksimal. Dalam pengamatan peneliti, disiplin kerja guru SMK 2 belum optimal, hal itu terlihat dari masalah, antara lain: tidak semua guru bisa mengerjakan tugas tepat waktu, masih ada guru yang datang terlambat. Jadi dilihat dari masalah disiplin guru sangat menurun sehingga kinerjanya tidak optimal.

Menurut Simanjuntak (2011) "Salah satu faktor yang mempengaruhi kinerja guru adalah kompetensi guru". Dalam UU No. 14 tahun 2005 disebutkan bahwa "Semua guru harus memiliki kompetensi dasar yang mencakup kompetensi pedagogis, kompetensi kepribadian, kompetensi sosial dan kompetensi profesional yang diperoleh melalui pendidikan profesional". Menurut Barinto (2012) "Kompetensi yang dimiliki oleh guru adalah komponen yang sangat menentukan dalam keberhasilan suatu pendidikan, sehingga kinerja guru perlu terus dioptimalkan". Ini wajar, karena guru adalah ujung tombak yang berurusan langsung dengan siswa sebagai subjek dan objek pembelajaran. Betapapun bagus dan idealnya kurikulum pendidikan, fasilitas dan infrastruktur pendidikan yang lengkap, dan seberapa kuat antusiasme siswa, tanpa diimbangi dengan kemampuan guru, semuanya akan menjadi kurang berarti.

Menurut Mulyasa (2011) mengatakan "Kompetensi pedagogik sangat penting karena menjadi penentu bagi keberhasilan proses pembelajaran yang secara langsung menyentuh kemampuan belajar termasuk manajemen siswa, perencanaan, desain implementasi, evaluasi hasil belajar dan pengembangan siswa sesuai kemampuan mereka".

\section{Rumusan Masalah.}

a. Adakah pengaruh secara parsial antara disiplin kerja terhadap kinerja guru di SMKN 2 Tangerang Selatan ?

b. Adakah pengaruh secara parsial antara kompetensi terhadap kinerja guru di SMKN 2 Tangerang Selatan?

c. Adakah pengaruh secara simultan antara disiplin kerja dan kompetensi terhadap kinerja guru di SMKN 2 Tangerang Selatan?

\section{Tujuan Penelitian.}

a. Untuk mengetahui pengaruh secara parsial antara disiplin kerja terhadap kinerja guru di SMKN 2 Tangerang Selatan.

b. Untuk mengetahui pengaruh secara parsial antara kompetensi terhadap kinerja guru di SMKN 2 Tangerang Selatan.

c. Untuk mengetahui pengaruh secara simultan antara disiplin kerja dan kompetensi terhadap kinerja guru di SMKN 2 Tangerang Selatan.

\section{B. KAJIAN TEORI}

\section{Disiplin Kerja.}

Disiplin merupakan sarana untuk melatih kepribadian pegawai agar senantiasa menunjukkan kinerja yang baik sikap, perilaku, dan pola kehidupan yang baik dan berdisiplin tidak berbentuk dalam waktu yang sangat lama salah satu proses untuk membentuk melalui proses pelatihan agar mencapai kinerja yang baik.

Menurut (Mangkunegara 2013) "Disiplin kerja merupakan kegiatan manajemen untuk memperteguh pedoman-pedoman organisasional". Indikator disiplin kerja diantaranya: Kehadiran, Ketaatan pada standar kerja, Etika kerja 


\section{Kompetensi.}

Seorang guru hendaknya berperilaku yang mempunyai pola interaksi di dalam proses belajar secara efektif, apabila mereka memiliki keinginan untuk memahamin peserta didik sesuai dengan kebutuhannya. Menurut Amstrong dan Baron (1998) dalam Wibowo (2014) "Kompetensi merupakan dimensi perilaku yang berada dibelakang kinerja kompeten. Seiring dinamakan kompetensi perilaku karena dimaksudkan untuk menjelaskan perannya dengan baik". Adapun indikator kompetensi adalah: Motif, Sifat, Konsep diri, Pengetahuan dan keterampilan.

\section{Kinerja Guru.}

Pengembangan kinerja guru merupakan factor yang amat menentukan keberhasilan proses pendidikan dan pembelajaran dalam era perkembangan pengetahuan yang sangat cepat dewasa ini pengembangan kinerja pada dasarnya menggambarkan kemampuan suatu profesi termaksuk profesi guru untuk terus menerus melakukan upaya peningkatan kompetensi yang berkaitan dengan peran dan tigas sebagai pendidik. Menurut Anwar Prabu Mangkunegara dalam Basrowi (2010) "Kinerja adalah hasil kerja secara kualitas dan kuantitas yang dicapai oleh seorang berdasarkan berbagai pendapat diatas, dapat kita simpulkan bahwa kinerja adalah sebuah wujud untuk kerja seseorang atau oganisasi secara keseluruhan dalam menjalankan tugas dan tanggung jawabnya dengan menggunakan standard dan kriteria tertentu sebagai acuan". Adapun Indikator kinerja di antaranya: Kualitas Kerja, Kecakapan Kerja, Kemampuan, Inisiatif.

\section{Kerangka Berpikir.}

Dalam setiap organisasi jelas memiliki ukuran pencapaian tujuan organisasi yang telah ditetapkan sebelumnya. Tercapai atau tidak akan terlihat dari hasil evaluasi yang dilakukan. Untuk mencapai tujuan tersebut tentunya organisasi harus dijalankan dengan sebaik mungkin dan berjalannya organisasi secara mendasar sangat ditentukan oleh pegawainya.

Dalam perspekstif organisasi, manajemen sumber daya manusia dipandang sebagai salah satu keunggulan yang kompetitif dan menjadi kunci penting dalam memastikan tujuan dapat dicapai. Disiplin kerja penting dimiliki oleh pegawai guna memastikan semua aturan dapat dijalankan dengan baik, begitu pula dengan kompetensi guru yang dimiliki harus dapat menjawab tantangan kebutuhan murid dalam memastikan proses belajar mengajar dapat berjalan dengan baik.

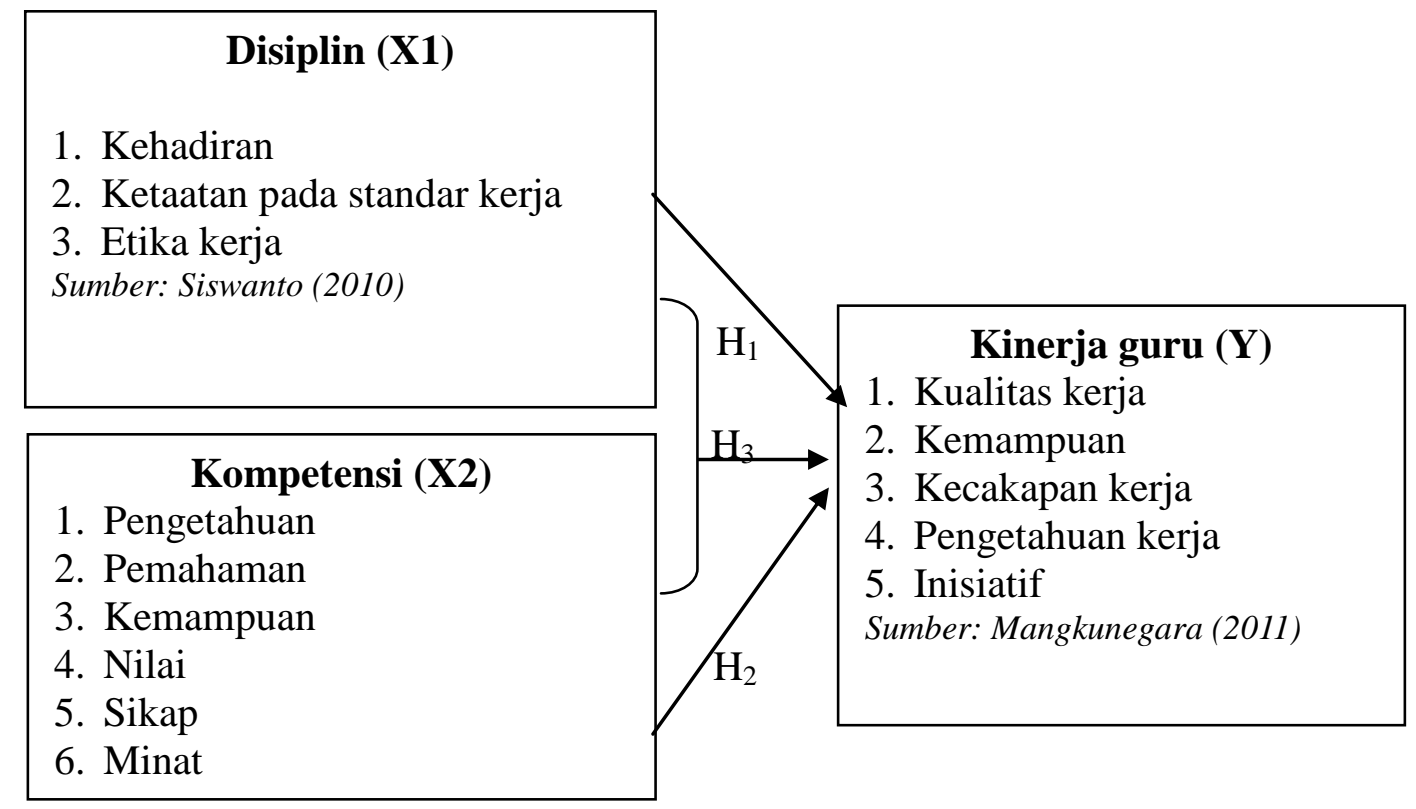

Gambar 1. Kerangka Berpikir 


\section{METODOLOGI PENELITIAN}

1. Obyek Penelitian.

Menurut Sugiyono (2016) berpendapat bahwa "Tempat penelitian merupakan sasaran ilmiah untuk mendapatkan data dengan tujuan dan kegunaan tertentu tentang sesuatu hal yang obyektif". Dalam penelitian ini dilakukan di SMK Negeri 2, Jl. Raya Pondok Aren No.52, Pondok Aren, Tangerang Selatan

\section{Populasi dan Sampel.}

a. Populasi

Menurut Sugiyono (2016) menyampaikan bahwa "Populasi adalah jumlah wilayah generalisasi yang terdiri atas obyek atau subyek yang mempunyai kualitas dan karakteristik yang ditetapkan oleh perusahaan dan kemudian ditarik kesimpulannya". Dalam penelitian ini populasinya adalah guru SMK Negeri 2 Tangerang Selatan.

b. Sampel

Menurut Sugiyono (2016) berpendapat "Sampel merupakan jumlah dan karakteristik yang dimiliki oleh populasi tersebut". Selanjutnya Sugiyono (2016) menjelaskan bahwa "Sampling jenuh merupakan teknik penentuan sampel apabila semua anggota populasi digunakan sebagai sampel". Dalam penelitian ini sampel yang digunakan 55 guru SMK Negeri 2 Tangerang Selatan.

\section{Teknik Penentuan Data.}

Teknik penentuan data dalam penelitian ini menggunakan data primer dan data sekunder sesuai dengan data yang peneliti perlukan.

\section{Metode Pengumpulan Data.}

Menurut Sugiyono (2016) berpendapat bahwa "Metode pengumpulan data merupakan cara ilmiah dalam mengumpulkan data yang valid dengan tujuan dapat dibuktikan, dikembangkan suatu pengetahuan sehingga dapat digunakan untuk memecahkan masalah". Dalam penelitian ini menggunakan kuesioner, studi pustaka, dan literatur lainnya.

\section{Metode Analisis Data.}

Metode analisis data merupakan alat analisis yang digunakan dalam penelitian. Menurut Sugiyono (2016) "Analisis data merupakan proses pencarian dan pengumpulan data yang dilakukan secara sistematis melalui wawancara, dokumentasi, dengn mengatur data kedalam kategori, menjelaskan satuan, mensintesis, mengatur dalam pola dan memilih mana yang penting dan sedang dipelajari serta menarik kesimpulan sehingga mudah dipahami oleh mereka sendiri dan orang lain. Dalam penelitian ini analisis yang digunakan meliputi analisis deskriptif dan analisis verifikatif.

\section{HASIL ANALISIS DATA}

\section{Uji Instrumen Penelitian}

a. Uji Validitas Data

Berdasarkan pengumpulan data yang sudah ditabulasi dan codding, selanjutnya data diuji valid atau tidak instrumen yang dibuat. Hasil ujinya sebagai berikut:

Tabel 1. Hasil Uji Validitas Variabel Disiplin Kerja (X1)

\begin{tabular}{|l|c|c|c|}
\hline Item Pernyataan & $\begin{array}{c}\text { Nilai } \\
\text { Chronbatch } \\
\text { Alpha }\end{array}$ & $\begin{array}{c}\text { Standar } \\
\text { Kritis }\end{array}$ & Keterangan \\
\hline 1. Pernah datang terlambat & 0.491 & 0.30 & Valid \\
\hline
\end{tabular}


ISSN (print) : 2598-9545 \& ISSN (online) : 2599-171X

\begin{tabular}{|l|l|l|l|}
\hline 2. Selalu hadir tepat waktu & 0.605 & 0.30 & Valid \\
\hline 3. Tingkat absensi saya selalu tinggi & 0.547 & 0.30 & Valid \\
\hline 4. Absensi kehadiran wajib diisi oleh guru & 0.492 & 0.30 & Valid \\
\hline 5. Mengerjakan pekerjaan sesuai standar & 0.369 & 0.30 & Valid \\
\hline 6. Melaksanakan tugas dengan baik & 0.484 & 0.30 & Valid \\
\hline 7. Guru selalu mematuhi standar kerja & 0.328 & 0.30 & Valid \\
\hline 8. Menekankan kejujuran dalam bekerja & 0.631 & 0.30 & Valid \\
\hline 9. Guru selalu memegang teguh komitmen & 0.631 & 0.30 & Valid \\
\hline 10. Hubungan kerja guru terjalin harmonis & 0.327 & 0.30 & Valid \\
\hline
\end{tabular}

Sumber: Data primer (diolah)

Berdasarkan hasil pengujian pada tabel di atas, seluruh item pernyataan pada variabel disiplin kerja disimpulkan valid, hal ini dibuktikan dengan nilai chronbatch alpha $>0.30$.

Tabel 2. Hasil Uji Validitas Variabel Kompetensi (X2)

\begin{tabular}{|l|c|c|c|}
\hline \multicolumn{1}{|c}{ Item Pernyataan } & $\begin{array}{c}\text { Nilai } \\
\text { Chronbatch } \\
\text { Alpha }\end{array}$ & $\begin{array}{c}\text { Standar } \\
\text { Kritis }\end{array}$ & Keterangan \\
\hline $\begin{array}{l}\text { 1. Menggunakan internet sebagai } \\
\text { informasi }\end{array}$ & 0.371 & 0.30 & Valid \\
\hline 2. Menguasai materi dengan baik & 0.357 & 0.30 & Valid \\
\hline 3. Memperdalam pemahaman materi ajar & 0.369 & 0.30 & Valid \\
\hline 4. Memahami kemampuan dasar siswa & 0.487 & 0.30 & Valid \\
\hline 5. Menerangkan materi pelajaran & 0.549 & 0.30 & Valid \\
\hline 6. Menerangkan konsep-konsep keilmuan & 0.518 & 0.30 & Valid \\
\hline 7. Memberikan soal sesuai tingkat kesulitan & 0.623 & 0.30 & Valid \\
\hline 8. Memberikan soal yang sepadan & 0.610 & 0.30 & Valid \\
\hline $\begin{array}{l}\text { 9. Melaksankan tugas mengajar dengan } \\
\text { baik }\end{array}$ & 0.632 & 0.30 & Valid \\
\hline $\begin{array}{l}\text { 10. guru menjelaskan setiap pokok } \\
\text { bahasan }\end{array}$ & 0.627 & 0.30 & Valid \\
\hline
\end{tabular}

Sumber: Data primer (diolah)

Berdasarkan hasil pengujian pada tabel di atas, seluruh item pernyataan pada variabel kompetensi disimpulkan valid, hal ini dibuktikan dengan nilai chronbatch alpha $>0.30$.

Tabel 3. Hasil Uji Validitas Variabel Kinerja Guru (Y)

\begin{tabular}{|l|c|c|c|}
\hline \multicolumn{1}{|c|}{ Item Pernyataan } & $\begin{array}{c}\text { Nilai } \\
\text { Chronbatch } \\
\text { Alpha }\end{array}$ & $\begin{array}{c}\text { Standar } \\
\text { Kritis }\end{array}$ & Keterangan \\
\hline 1.Menggapi pertanyaan siswa dengan baik & 0.425 & 0.30 & Valid \\
\hline 2. Menguasai materi pembelajaran & 0.593 & 0.30 & Valid \\
\hline 3. Memiliki kemampuan yang baik & 0.333 & 0.30 & Valid \\
\hline $\begin{array}{l}\text { 4. Menyelesaikan tugas sesuai } \\
\text { kemampuan }\end{array}$ & 0.768 & 0.30 & Valid \\
\hline 5. Memberikan informasi dengan cepat & 0.512 & 0.30 & Valid \\
\hline 6. Informasi kemajuan siswa & 0.507 & 0.30 & Valid \\
\hline 7. Memberi contoh kehidupan sehari-hari & 0.601 & 0.30 & Valid \\
\hline 8. Menambah pengetahuan dengan belajar & 0.380 & 0.30 & Valid \\
\hline 9. Memberika ide-ide kepada guru & 0.350 & 0.30 & Valid \\
\hline 10. Memberikan ide kreatif pada siswa & 0.358 & 0.30 & Valid \\
\hline
\end{tabular}

Sumber: Data primer (diolah) 
Berdasarkan hasil pengujian pada tabel di atas, seluruh item pernyataan pada variabel kinerja guru disimpulkan valid, hal ini dibuktikan dengan nilai chronbatch alpha $>0.30$.

b. Uji Reliabilitas Data

Pengujian instrumen berikutnya adalah uji reliabilitas sebagai kelanjutan apakah responden konsisten dalam memberikan jawaban pernyataan yang dibuat. Hasil pengujian sebagai berikut:

\begin{tabular}{|l|c|c|c|}
\hline \multicolumn{1}{|c}{ Variabel } & \multicolumn{1}{c}{$\begin{array}{c}\text { Nilai Chronbatch } \\
\text { Alpha }\end{array}$} & $\begin{array}{c}\text { Standar } \\
\text { Kritis }\end{array}$ & Keterangan \\
\hline Disiplin Kerja (X1) & 0.650 & 0.60 & Reliabel \\
\hline Kompetensi (X2) & 0.690 & 0.60 & Reliabel \\
\hline Kinerja Guru (Y) & 0.637 & 0.60 & Reliabel \\
\hline
\end{tabular}

Sumber: Data primer (diolah)

Berdasarkan hasil pengujian pada tabel di atas, seluruh item pernyataan pada variabel disiplin kerja, kompetensi dan kinerja guru disimpulkan valid, hal ini dibuktikan dengan nilai chronbatch alpha $>0.60$.

\section{Uji Asumsi Klasik (Kelayakan Data)}

\section{a. Uji Normalitas Data}

Pengujian Normalitas digunakan untuk mengetahui apakah data yang akan dipakai sebagai data penelitian benar-benar distribusinya memenuhi unsur normal atau tidak. Dalam pengujian ini digunakan Kolmogorov-Smirnov test. Adapun hasil pengujiannya sebagai berikut:

Tabel 5. Hasil Uji Normalitas Dengan Kolmogorof=Smrirnov Test.

Tests of Normality

\begin{tabular}{|c|c|c|c|c|c|c|}
\hline & \multicolumn{3}{|c|}{ Kolmogorov-Smirnov ${ }^{\mathrm{a}}$} & \multicolumn{3}{|c|}{ Shapiro-Wilk } \\
\hline & Statistic & df & Sig. & $\begin{array}{l}\text { Statisti } \\
\text { C }\end{array}$ & df & Sig. \\
\hline Kinerja Guru $(Y)$ & .108 & & .200 & .977 & 50 & \\
\hline
\end{tabular}

${ }^{*}$. This is a lower bound of the true significance.

a. Lilliefors Significance Correction

Sumber: Data primer (diolah)

Berdasarkan hasil pengujian Kolmogorof=Smrirnov Test diperoleh nilai Probability signifikansi 0,200 >0,05. Dengan demikian data yang digunakan memenuhi unsur normal.

\section{b. Uji Multikolinieritas Data}

Uji multikolinieritas digunakan untuk menguji apakah antar variabel independen memiliki hubungan korelasi atau tidak. Model regresi yang baik seharusnya tidak memiliki korelasi antar variabel bebasnya. Dalam penelitin ini uji multikolinieritas dilakukan dengan SPSS Versi 24 dengan melihat tolerance value dengan Variance Inflation Factor (FIV). Adapun hasil hasil pengujian data sebagai berikut:

Tabel 6. Hasil Uji Colinierity Statistic Test.

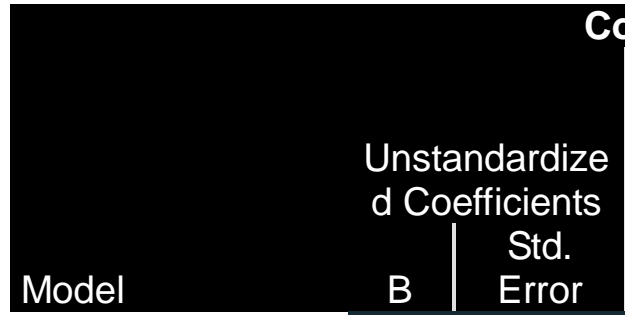

\begin{tabular}{|c|} 
Coefficients $^{\text {a }}$ \\
Standardi \\
zed \\
Coefficien \\
ts \\
Beta
\end{tabular}
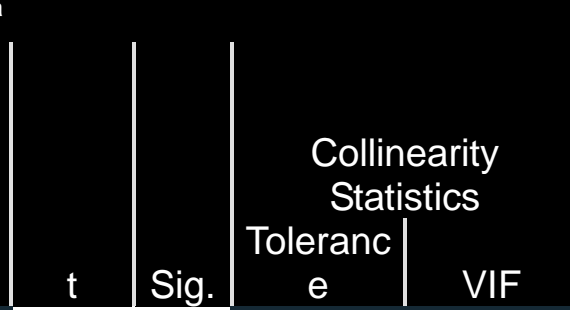


\begin{tabular}{l|r|r|r|r|r|r|r}
\hline 1 (Constant) & 9.04 & 3.912 & & 2.311 & .02 & & \\
\hline $\begin{array}{l}\text { Disiplin Kerja } \\
\text { (X1) }\end{array}$ & .358 & .107 & .387 & 3.352 & .00 & .694 & 1.441 \\
\hline $\begin{array}{l}\text { Kompetensi } \\
\text { (X2) }\end{array}$ & .423 & .105 & .466 & 4.039 & .00 & .694 & 1.441 \\
\hline
\end{tabular}

a. Dependent Variable: Kinerja Guru $(\mathrm{Y})$

Sumber: Data primer (diolah)

Berdasarkan hasil uji colinierty statistic test diperoleh nilai tolerance masingmasing variabel independen 0,694 < 1.0 serta nilai Variance Inflation Factor sebesar $1,441<10$. Dengan demikian model regresi yang digunakan tidak ada gangguan multikolinieritas sehingga data layak untuk dilanjutkan sebagai data penelitian

c. Uji Autokorelasi Data

Authocorrelation test dimaksudkan untuk menguji apakah antar anggota sampel terdapat penyimpangan data. Data yang baik tidak terjadi penyipangan. Dalam penelitin ini digunakan Darbin Watson Test. Adapun hasil hasil pengujian data sebagai berikut:

Tabel 7. Hasil Uji Durbin Watson Test.

\begin{tabular}{ll|r|r|r|r} 
& & \multicolumn{3}{c|}{ Model Summary $^{\mathbf{b}}$} \\
Model & $\mathrm{R}$ & R Square & $\begin{array}{c}\text { Adjusted } \\
\text { R Square }\end{array}$ & $\begin{array}{c}\text { Std. Error of } \\
\text { the Estimate }\end{array}$ & Durbin-Watson \\
\hline 1 & $.752^{\mathrm{a}}$ & .566 & .547 & 2.37449 & 2.171 \\
\hline
\end{tabular}

a. Predictors: (Constant), Kompetensi (X2), Disiplin Kerja (X1)

b. Dependent Variable: Kinerja Guru (Y)

Sumber: Data primer (diolah)

Berdasarkan hasil pengujian pada tabel di atas, diperoleh nilai Durbin Watson sebesar 2,171 dimana nilai tersebut berada pada interval 1,550-2,460 dan sesuai ketentuan maka data tidak terjadi gangguan autokorelasi.

d. Uji HeteroskesdastisitasData

Dalam penguijian ini digunakan Glejser Test, yaitu menguji apakan dalam model regresi yang digunakan terjadi ketidaksamaan varians residual. Adapun hasil pengujian sebagai berikut:

Tabel 8. Hasil Uji Glejser Test Model

\begin{tabular}{|c|c|c|c|c|c|}
\hline Model & $\begin{array}{r}\text { C } \\
\text { Unstan } \\
\text { Coef } \\
\text { B }\end{array}$ & $\begin{array}{l}\text { fficients } \\
\text { ardized } \\
\text { ients } \\
\text { Std. } \\
\text { Error }\end{array}$ & $\begin{array}{l}\text { Standardized } \\
\text { Coefficients } \\
\text { Beta }\end{array}$ & $t$ & Sig. \\
\hline $1 \quad$ (Constant) & 6.516 & 2.367 & & 2.752 & .008 \\
\hline Disiplin Kerja (X1) & -.098 & .065 & -.255 & -1.525 & .134 \\
\hline Kompetensi (X2) & -.023 & .063 & -.060 & -.356 & .724 \\
\hline
\end{tabular}

a. Dependent Variable: RES2

Sumber: Data primer (diolah)

Berdasarkan hasil pengujian pada tabel di atas, diperoleh nilai Prob.Sig variabel disiplin kerja sebesar 0,134 dan kompetensi sebesar 0,724 dimana kedua-duanya $>0,05$. Dengan demikian disimpulkan bahwa data yang digunakan tidak terjadi gangguan heteroskesdastisitas. 


\section{Analisis Deskriptif (Kualitatif)}

Untuk selanjutnya dilakukan analisis deskriptif dan analisis verifikatif dimana akan dicari nilai pengaruh antara variabel independen terhadap variabel depedennya.

Analisis statistik deskriptif ini untuk memperoleh gambaran suatu data yang dipakai dalam penelitian dilihat dari nilai minimum dan nilai maksimum rata-rata (mean) serta standar deviasi (Ghozali, 2016). Dalam penelitian ini variabel yang digunakan adalah disiplin kerja, kompetensi dan kinerja guru. Adapun hasil analisis sebagai berikut:

Tabel 9 Descriptif Statistik Mean Score Variabel.

\begin{tabular}{lr|r|r|r|r} 
& & \multicolumn{6}{|c|}{ Descriptive Statistics } & \\
& $\mathrm{N}$ & Minimum & $\begin{array}{l}\text { Maximu } \\
\mathrm{m}\end{array}$ & \multicolumn{1}{c|}{ Mean } & \multicolumn{1}{c}{ Std. Deviation } \\
\hline $\begin{array}{l}\text { Disiplin Kerja } \\
\text { (X1) }\end{array}$ & 50 & 31 & 48 & 39.20 & 3.817 \\
\hline $\begin{array}{l}\text { Kompetensi } \\
\text { (X2) }\end{array}$ & 50 & 30 & 46 & 38.78 & 3.888 \\
\hline $\begin{array}{l}\text { Kinerja Guru } \\
\text { (Y) }\end{array}$ & 50 & 31 & 48 & 39.46 & 3.529 \\
\hline $\begin{array}{l}\text { Valid N } \\
\text { (listwise) }\end{array}$ & 50 & & & & \\
\hline
\end{tabular}

Sumber: Data primer (diolah)

Berdasarkan hasil pengujian pada tabel di atas, dari 50 sampel yang digunakan untuk variabel disiplin kerja diperoleh nilai terendah (minimum) sebesar 31, nilai tetinggi (maximum) sebesar 48, nilai rata-rata (mean) sebesar 39,20 dan nilai standar deviasi sebesar 3,817.

Sedangkan untuk variabel kompetensi diperoleh nilai terendah (minimum) sebesar 30 , nilai tetinggi (maximum) sebesar 46, nilai rata-rata (mean) sebesar 38,79 dan nilai standar deviasi sebesar 3,888.

Dan untuk variabel kinerja guru diperoleh nilai terendah (minimum) sebesar 31 , nilai tetinggi (maximum) sebesar 48, nilai rata-rata (mean) sebesar 39,46 dan nilai standar deviasi sebesar 3,529.

Ketiga variabel memiliki nilai rata-rata skor yang berada diantara rentang skala 34,00-41,900 dalam kriteria yang baik.

\section{Analisis Verifikatif (Kuantitatif)}

a. Analisis Regresi Berganda

Regression Multiple Analysis digunakan untuk menguji pengaruh antara variabel independen terhadap dependen dalam arti mengetahui perubahan variabel dependen jika variabel independennya mengalami perubahan. Dalam penelelitian ini digunakan Unstandarized Coeficien Model. Adapun hasil pengujiannya sebagai berikut:

Tabel 10 Hasil Uji Regression Model.

\begin{tabular}{|c|c|c|c|c|c|}
\hline & & Coeffic & $\operatorname{nis}^{a}$ & & \\
\hline & $\begin{array}{l}\text { Unstan } \\
\text { Coeff }\end{array}$ & $\begin{array}{l}\text { ardized } \\
\text { ients }\end{array}$ & $\begin{array}{l}\text { Standardized } \\
\text { Coefficients }\end{array}$ & & \\
\hline Model & & $\begin{array}{l}\text { Std. } \\
\text { Error }\end{array}$ & & $t$ & Sig. \\
\hline $1 \quad$ (Constant) & 9.041 & 3.912 & & 2.311 & .025 \\
\hline $\begin{array}{l}\text { Disiplin Kerja } \\
\text { (X1) }\end{array}$ & .358 & .107 & .387 & 3.352 & .002 \\
\hline Kompetensi (X2) & .423 & .105 & .466 & 4.039 & .000 \\
\hline
\end{tabular}


a. Dependent Variable: Kinerja Guru (Y)

Sumber: Data primer (diolah)

Berdasarkan hasil pengujian pada tabel di atas, diperoleh persamaan regresi $Y$ $=9,041+0,358 \times 1+0,423 \times 2$. Nilai coefisien regression (betta) bernilai positif. Nilai persamaan ini memiliki makna sebagai berikut:

1) Nilai konstanta sebesar 9,041 diartikan bahwa apabila variabel disiplin kerja dan kompetensi tidak ada atau 0 (konstan), maka sudah terbentuk nilai kinerja guru sebesar 9,041 atau ada $9,041 \%$.

2) Coeficien regression sebesar 0,358 angkanya positif artinya apabila disiplin kerja mengalami kenaikan sebesar 0,358 point maka kinerja guru juga akan mengalami peningkatan sebesar 0,358 point.

3) Coeficien regression sebesar 0,423 angkanya positif artinya apabila kompetensi mengalami kenaikan sebesar 0,423 point maka kinerja guru juga akan mengalami peningkatan sebesar 0,423 point.

\section{b. Analisis Koefisien Korelasi}

Coefocient Correlation Analysis digunakan untuk mengetahui tingkat kekuatan pengaruh antara variabel independen terhadap variabel dependen. Dalam penelelitian ini digunakan Coefocient Correlation Test. Adapun hasil pengujiannya sebagai berikut:

Tabel 11 Hasil Uji Correlation Test Variabel Disiplin Kerja (X1)

\begin{tabular}{llr|r} 
& \multicolumn{1}{c}{ Correlations $^{\text {b }}$} & $\begin{array}{r}\text { Disiplin Kerja } \\
(\mathrm{X} 1)\end{array}$ & \multicolumn{1}{c|}{$\begin{array}{c}\text { Kinerja Guru } \\
(\mathrm{Y})\end{array}$} \\
\hline Disiplin Kerja (X1) & Pearson Correlation & 1 & $.644^{* *}$ \\
\cline { 2 - 4 } & Sig. (2-tailed) & & .000 \\
\hline Kinerja Guru (Y) & Pearson Correlation & $.644^{* *}$ & 1 \\
\cline { 2 - 4 } & Sig. (2-tailed) & .000 & \\
\hline
\end{tabular}

**. Correlation is significant at the 0.01 level (2-tailed).

b. Listwise $\mathrm{N}=50$

Sumber: Data primer (diolah)

Berdasarkan hasil pengujian pada tabel di atas, diperoleh nilai korelasi sebesar 0,644 , dimana nilai tersebut berada pada rentang skala 0,600-0,799, dengan demikian disiplin kerja memiliki tingkat perngaruh yang kuat terhadap kinerja guru.

Tabel 12 Hasil Uji Correlation Test Variabel Kompetensi (X2)

\begin{tabular}{llr|r} 
& \multicolumn{1}{c}{ Correlations $^{\mathrm{b}}$} & $\begin{array}{c}\text { Kompetensi } \\
(\mathrm{X} 2)\end{array}$ & \multicolumn{1}{c}{$\begin{array}{c}\text { Kinerja Guru } \\
(\mathrm{Y})\end{array}$} \\
\hline Kompetensi $(\mathrm{X} 2)$ & Pearson Correlation & 1 & $.680^{* *}$ \\
\cline { 2 - 4 } & Sig. (2-tailed) & & .000 \\
\hline Kinerja Guru (Y) & Pearson Correlation & $.680^{* *}$ & 1 \\
\cline { 2 - 5 } & Sig. (2-tailed) & .000 & \\
\hline
\end{tabular}

**. Correlation is significant at the 0.01 level (2-tailed).

b. Listwise $\mathrm{N}=50$

Sumber: Data primer (diolah)

Berdasarkan hasil pengujian pada tabel di atas, diperoleh nilai korelasi sebesar 0,680 , dimana nilai tersebut berada pada rentang skala 0,600-0,799, dengan demikian kompetensi memiliki tingkat perngaruh yang kuat terhadap kinerja guru.

Tabel 13 Hasil Uji Correlation Test Variabel Disiplin Kerja (X1) dan Kompetensi (X2) Secara Simultan 


\begin{tabular}{ll|r|r|r} 
& & \multicolumn{3}{|c|}{ Model Summary } \\
Model & $\mathrm{R}$ & R Square & $\begin{array}{c}\text { Adjusted R } \\
\text { Square }\end{array}$ & Std. Error of the Estimate \\
\hline 1 & $.752^{\mathrm{a}}$ & .566 & .547 & 2.37449 \\
\hline
\end{tabular}

a. Predictors: (Constant), Kompetensi (X2), Disiplin Kerja (X1)

Sumber: Data primer (diolah)

Berdasarkan hasil pengujian pada tabel di atas, diperoleh nilai korelasi sebesar 0,753, dimana nilai tersebut berada pada rentang skala 0,600-0,799, dengan demikian disiplin kerja dan kompetensi secara simultan memiliki tingkat perngaruh yang kuat terhadap kinerja guru.

\section{c. Analisis Koefisien Deteminasi}

Analisis koefisien determinasi digunakan untuk mengetahui konstribusi besarnya pengaruh antara variabel independen terhadap variabel dependen. Dalam penelelitian ini digunakan Model Sumarry Test. Adapun hasil pengujiannya sebagai berikut:

Tabel 14 Hasil Uji Koefisien Determinasi Variabel Disiplin Kerja (X1)

\begin{tabular}{lc|c|c|c} 
& & \multicolumn{2}{c}{ Model Summary } \\
Model & $\mathrm{R}$ & $\begin{array}{c}\text { Adjusted R } \\
\text { Square }\end{array}$ & \multicolumn{2}{c}{$\begin{array}{c}\text { Std. Error of the } \\
\text { Estimate }\end{array}$} \\
\hline 1 & $\mathrm{R}$ & Square & Squar & 2.72705 \\
\hline
\end{tabular}

a. Predictors: (Constant), Disiplin Kerja (X1)

Sumber: Data primer (diolah)

Berdasarkan hasil pengujian pada tabel di atas, diperoleh nilai koefisien determinasi ( $R$ Square) sebesar 0,415. Artinya variabel disiplin kerja memiliki pengaruh sebesar $41,5 \%$ terhadap kinerja guru.

Tabel 15 Hasil Uji Koefisien Determinasi Variabel Kompetensi (X2)

\begin{tabular}{|c|c|c|c|c|}
\hline \multicolumn{5}{|c|}{ Model Summary } \\
\hline$M$ & & $\mathrm{R}$ & Adjusted R & Std. Error of the \\
\hline 1 & $\mathrm{R}$ & $\begin{array}{r}\text { square } \\
.462\end{array}$ & square & Estımate \\
\hline
\end{tabular}

a. Predictors: (Constant), Kompetensi (X2)

Sumber: Data primer (diolah)

Berdasarkan hasil pengujian pada tabel di atas, diperoleh nilai koefisien determinasi ( $R$ Square) sebesar 0,462. Artinya variabel kompetensi memiliki pengaruh sebesar $46,2 \%$ terhadap kinerja guru.

Tabel 16 Hasil Uji Koefisien Determinasi Variabel Disiplin Kerja (X1) dan

Kompetensi (X2) Secara Simultan

\begin{tabular}{ll|r|r|r|} 
& \multicolumn{4}{|c|}{ Model Summary } \\
Model & $\mathrm{R}$ & $\mathrm{R}$ Square & Adjusted R Square & Std. Error of the Estimate \\
\hline 1 & $.752^{\mathrm{a}}$ & .566 & .547 & 2.37449 \\
\hline
\end{tabular}

a. Predictors: (Constant), Kompetensi (X2), Disiplin Kerja (X1)

Sumber: Data primer (diolah)

Berdasarkan hasil pengujian pada tabel di atas, diperoleh nilai koefisien determinasi ( $R$ Square) sebesar 0,566. Artinya variabel disiplin kerja dan kompetensi secara bersama-sama memiliki pengaruh sebesar 56,6\% terhadap kinerja guru, sisanya sebesar $41,4 \%$ dipengaruhi faktor lain. 


\section{d. Uji Hipotesis}

Pengujian hipotesis dimaksudkan untuk mengetahui hipotesis mana yang sebaiknya ditolak atau yang diterima. Dalam penelitian ini digunakan uji t (parsial) dan uji F (Simultan). Adapun rumusan hipotesis yang dibuat adalah sebagai berikut:

Hipotesis pertama: Terdapat pengaruh positif dan signifikan secara parsial antara disiplin kerja terhadap kinerja guru pada SMK Negeri 2 Tangerang Selatan.

Hipotesis kedua: $\quad$ Terdapat pengaruh positif dan signifikan secara parsial antara kompetensi terhadap kinerja guru pada SMK Negeri 2 Tangerang Selatan.

Hipotesis ketiga: Terdapat pengaruh positif dan signifikan secara simultan antara disiplin kerja dan kompetensi terhadap kinerja guru pada SMK Negeri 2 Tangerang Selatan.

Adapun hasil pengujian sebagai beikut:

Tabel 17 Hasil Uji hipotesis (Uji t) Disiplin Kerja (X1)

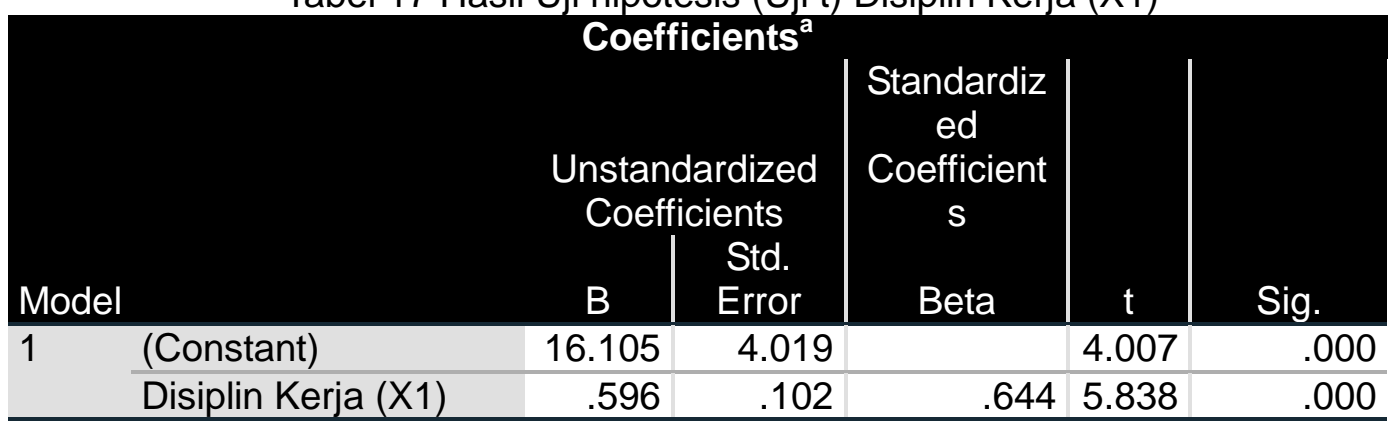

a. Dependent Variable: Kinerja Guru $(\mathrm{Y})$

Sumber: Data primer (diolah)

Berdasarkan hasil pengujian pada tabel di atas, diperoleh nilai probability signifikansi $0,000<0,05$. Dengan demikian hipotesis pertama diterima artinya terdapat pengaruh positif dan signifikan secara parsial antara disiplin kerja terhadap kinerja guru pada SMK Negeri 2 Tangerang Selatan

Tabel 18 Hasil Uji hipotesis (Uji t) Kompetensi (X2)

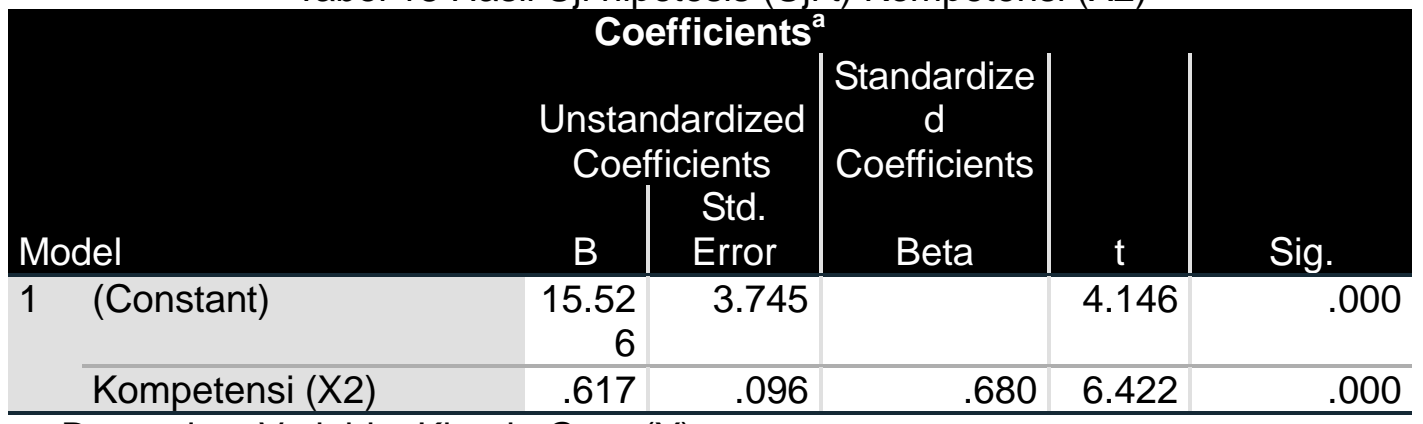

a. Dependent Variable: Kinerja Guru $(\mathrm{Y})$

Sumber: Data primer (diolah)

Berdasarkan hasil pengujian pada tabel di atas, diperoleh nilai probability signifikansi $0,000<0,05$. Dengan demikian hipotesis kedua diterima artinya terdapat pengaruh positif dan signifikan secara parsial antara kompetensi terhadap kinerja guru pada SMK Negeri 2 Tangerang Selatan

Tabel 19 Hasil Uji hipotesis (Uji F) Disiplin Kerja (X1) dan Kompetensi (X2)

\begin{tabular}{|c|c|c|c|c|c|c|}
\hline \multicolumn{7}{|c|}{ ANOVA $^{\mathrm{a}}$} \\
\hline \multicolumn{2}{|c|}{ Model } & $\begin{array}{l}\text { Sum of } \\
\text { Squares }\end{array}$ & df & $\begin{array}{l}\text { Mean } \\
\text { Square }\end{array}$ & $F$ & Sig. \\
\hline 1 & Regression & 345.425 & 2 & 172.713 & 30.633 & $.000^{b}$ \\
\hline & Residual & 264.995 & 47 & 5.638 & & \\
\hline
\end{tabular}


a. Dependent Variable: Kinerja Guru $(Y)$

b. Predictors: (Constant), Kompetensi (X2), Disiplin Kerja (X1)

Sumber: Data primer (diolah)

Berdasarkan hasil pengujian pada tabel di atas, diperoleh nilai probability signifikansi $0,000<0,05$. Dengan demikian hipotesis ketiga diterima artinya terdapat pengaruh positif dan signifikan secara simultan antara disiplin kerja dan kompetensi terhadap kinerja guru pada SMK Negeri 2 Tangerang Selatan.

\section{E. KESIMPULAN DAN SARAN}

\section{Kesimpulan}

Berdasarkan uiraian dan hasil analisis mengenai pengaruh disiplin kerja dan kompetensi terhadap kinerja guru pada SMKNegeri 2 Tangerang Selatan, maka dapat disimpulkan sebagai berikut:

a. Disiplin kerja berpengaruh positif dan signifikan terhadap kinerja guru dengan nilai korelasi sebesar 0,644 artinya kedua variabel memiliki tingkat pengaruh yang kuat dengan konstribusi pengaruh sebesar $41,5 \%$. Uji hipotesis diperoleh probability signifikansi $0,000<0,05$.

b. Kompetensi berpengaruh positif dan signifikan terhadap kinerja guru dengan nilai korelasi sebesar 0,680 artinya kedua variabel memiliki tingkat pengaruh yang kuat dengan konstribusi pengaruh sebesar $46,2 \%$. Uji hipotesis diperoleh probability signifikansi $0,000<0,05$.

c. Disiplin kerja dan kompetensi secara simultan berpengaruh positif dan signifikan terhadap kinerja guru dengan nilai korelasi sebesar 0,752 artinya kedua variabel memiliki tingkat pengaruh yang kuat dengan konstribusi pengaruh sebesar $56,6 \%$. Uji hipotesis diperoleh probability signifikansi $0,000<0,05$.

\section{Saran}

a. Disiplin kerja pernyataan yang paling lemah adalah 3,78 dimana hanya mencapai skor sebesar 3,68, meskipun dalam kriteria baik namun masih ada 29,2\% responden yang menyatakan kurang setuju dan tidak setuju. Untuk lebih baik lagi sekolah harus mendorong guru untuk menjalin hubungan baik antar guru.

b. Disiplin kerja pernyataan yang paling lemah adalah 3,68 dimana hanya mencapai skor sebesar xx, meskipun dalam kriteria baik namun masih ada 33\% responden yang menyatakan kurang setuju dan tidak setuju. Untuk lebih baik lagi kompetensi juga penting dalam meningkatkan dan mewujudkan kemampuan sesuatu sesuai tugas yang diberikan kepada seseorang.

c. Pengaruh disiplin kerja dan kompetensi terhadap kinerja pegawai sebesar $56,6 \%$. Untuk lebih baik lagi sekolah melakukan tindakan dengan memberikan informasi secara cepat kepada guru lainnya 


\section{F. DAFTAR PUSTAKA}

Algifari, “Analisis Regresi”, Yogyakarta, 2011.

Anwar Prabu Mangkunegara, "Sumber Kerangka Berfikir Kinerja". Gramedia, Jakarta Selatan, 2010

Andi Supangat, "Statistika dalam Kajian Deskriftif, Inferensi dan Non Parametic", Edisi Pertama, Kencana Prenada Media Group, Jakarta, 2014.

Bangun, Wilson. “Manajemen Sumber Daya Manusia”. Erlangga, Bandung, 2012.

Barinto, "Hubungan Kompetensi Guru dan Supervisi Akademik dengan Kinerja Guru", 2012.

Buchari, Zainun. “Manajemen dan Motivasi”. Balai Aksara, Jakarta, 2015

Depdiknas. "Tugas dan peran Kepala Sekolah Dalam Manajemen Kurikulum”. Binatama Raya. Jakarta, 2010.

Ghozali, Imam, "Aplikasi Analisis Multivariate dengan Program SPSS", Edisi Kelima, Badan Penerbit Undip, Semarang, 2014.

Handoko, "Manajemen Personalia dan Sumberdaya Manusia”, Edisi Kelima, BPFE UGM, Yogyakarta, 2012.

Hasibuan, SP Malayu, "Manajemen Sumber Daya Manusia”, Cetakan ketujuh, belas, Penerbit PT. Bumi Aksara, Jakarta, 2013.

Hasibuan, SP Malayu, "Manajemen Sumber Daya Manusia”, Cetakan Ketujuh, PT Bumi Aksara, Jakarta, 2015.

Hasibuan, SP Malayu. "Manajemen Sumber Daya Manusia”, Penerbit PT. Bumi Aksara, Jakarta, 2014.

Istijianto, “Aplikasi Praktis Riset Pemasaran”, Gramedia Pustaka Utama, Jakarta, 2014.

Penggabean, S. Mutiara. "Manajemen Sumber Daya Manusia”. Ghalia Indonesia, Bogor, 2015.

Rivai, Veithzal, “Manajemen Sumber Daya Manusia”, Penerbit PT. Raja Grafindo Persada, Jakarta, 2010.

Salam, “Manajemen Pemerintahan Indonesia”. PT. Djambatan, Jakarta, 2014.

Sedarmayanti. "Manajemen Sumber Daya Manusia, Reformasi Birokrasi dan Manajemen Pegawai Negeri Sipil”, Cetakan Kelima, PT Refika Aditama, Bandung, 2014.

Santoso, Singgih, "SPSS Statistik Parametik” Cetakan Kedua, PT. Elek Media, 2015.

Simanjuntak, J. Payaman. "Manajemen \& evaluasi Kinerja”. FEUI, 2011 
Sinambela, Lijan Poltak, "Manajemen Sumber Daya Manusia". Bumi Aksara, Jakarta, 2016.

Siswanto dan Agus, "Manajemen Sumber Daya Manusia” PT. Gramedia Pustaka, Jakarta, 2013.

Suharsimi Arikunto "Prosedur Penelitian Suatu Pendekatan Praktek", PT. Rineka Cipta, Jakarta, 2013.

Supriyadi. “Strategi Belajar Mengajar”, Jaya IImu, Yogyakarta, 2014.

Sunyoto, Danang. "Manajemen Sumber Daya Manusia”, Cetakan Pertama. CAPS (Center for Academic Publishing Service), Yogyakarta, 2012.

Sutrisno, Edy, "Manajemen Sumber Daya Manusia,", Edisi Pertama, Penerbit Kencana, Jakarta, 2011

Sutrisno, Edy. "Manajemen Sumber Daya Manusia”, Cetakan Pertama, Penerbit Kencana, Jakarta, 2015

Sugiyono, "Metode Penelitian Kuantitatif Kualitatif dan $R \& D$ ", Penerbit CV. Alfabeta, Bandung, 2016.

Wibowo. "Manajemen Kinerja", Cetakan Keenam Edisi Ketiga, Raja Grafindo Persada, Jakarta, 2014. 